\title{
Experimental Results of Ship-to-ship Stabilized Mooring System for Mobile Harbor
}

\author{
Tae-Gweon Jeong* • Yun-Sok Lee*** Chao Chen*** • + Se-Won Kim \\ * Division of Navigation Science, Korea Maritime University, Busan 606-791, Republic. of Korea \\ ** Sea Training Center,Korea Maritime University, Busan 606-791, Republic. of Korea \\ *** Marine Simulation Center,Korea Maritime University, Busan 606-791, Republic. of Korea \\ + Division of Navigation Science, Korea Maritime University, Busan 606-791, Republic. of Korea
}

\begin{abstract}
A new concept of ocean transport system, called mobile harbor, was introduced as a feasibility study in Korea in 2009. Target of the mobile harbor is a short distance transport of containers with or without cargo handling cranes. Although the mobile harbor project has a lot of topics to deal with, this paper is to focus on only ship-to-ship stabilized mooring, which plays a key role in cargo handling. The ship-to-ship stabilized mooring system was developed and installed on board a barge of LOA 32m and breadth $12 \mathrm{~m}$. The dockside tests as sea test were carried out so as to ascertain whether the systems can work well to control the barge's motion. The results of dockside test showed that the heave motion of the barge's motion can be reduced by more than $45 \%$.
\end{abstract}

Key words : mobile harbor, mother ship, mobile harbor ship, ship-to-ship stabilized mooring system, positioning winch, embedment drag anchor

\section{Introduction}

A new concept of ocean transport system, called mobile harbor, was introduced as a feasibility study in Korea in 2009. Target of the mobile harbor is a short distance transport of containers with or without cargo handling cranes. Many study groups for the mobile harbor carried out their own fields and frequently had group discussions about them(Jang,2009;Kim,2009;Lee,2009;Myung,2009;Park,2009; Shin,2009). That is, they investigated a series of conceptual designs and operational feasibility of the mobile harbor, such as the size of mobile harbor and mother ship, design, working sea state, cargo handling speed, motion analysis for floating structure, actuator analysis, mooring and berthing method, control system for mobile harbor ship, mooring line and cargo handling crane, proper location for mobile harbor service, etc.

The very important aspect among them is operation requirements under the sea state three. The motion of a mobile harbor ship (hereafter "MH ship"), which is moored at a container ship called a mother ship, should be controlled to meet cargo handling smoothly. However, the cargo handling at the land-based wharf would be done at a higher speed than that on board the $\mathrm{MH}$ ship. Although there are a lot of topics to do smooth cargo handling on board the $\mathrm{MH}$ ship, this paper is to deal with only ship-to-ship stabilized mooring system (hereafter "SMS").

The ship-to-ship SMS is one of important parts of mobile harbor project and consists of the optimum SMS and specialized equipment involved in it. For the optimum SMS, mooring method is that one side of the MH ship is securely moored alongside a mother ship by mooring lines and Yokohama fenders between them and the other moored at the sea bottom by fore and aft suction pile anchors. Positioning winch systems, which are originally modified from conventional auto-tension ones, should be developed together with control system in this study. The winch systems are to measure and control the motion variation of the $\mathrm{MH}$ ship by suppressing the surge and sway motion, especially, the heave motion.

Sea tests are planned to be two stages; the first is carried out dockside and the other alongside the mother ship. This study is to deal with dockside tests as the first stage of the sea tests, which are to find out the difference of the motion of the $\mathrm{MH}$ ship between without the control of the positioning winch systems and with it. After all it will be ascertained whether the winch systems can work well to control these motions or not.

\footnotetext{
* Representing author, tgjeong@.hhu.ac.kr, 051)410-4246

**1ys@hhu.ac.kr, 051)410-5098

*** cc20202@163.com, 051)410-4856

+ Corresponding author, swkim@hhu.ac.kr, 051)410-4278
} 


\section{The Conceptual Design and Mooring of Mobile Harbor}

One of the conceptual designs of mobile harbor here was suggested as shown in Fig. 1. The design is intended for the optimum SMS. Firstly a mother ship of 10,000 TEU class will be anchored with four (4) suction pile anchors and each MH ship moored with two (2) suction pile anchors and two (2) bollards of the mother ship.

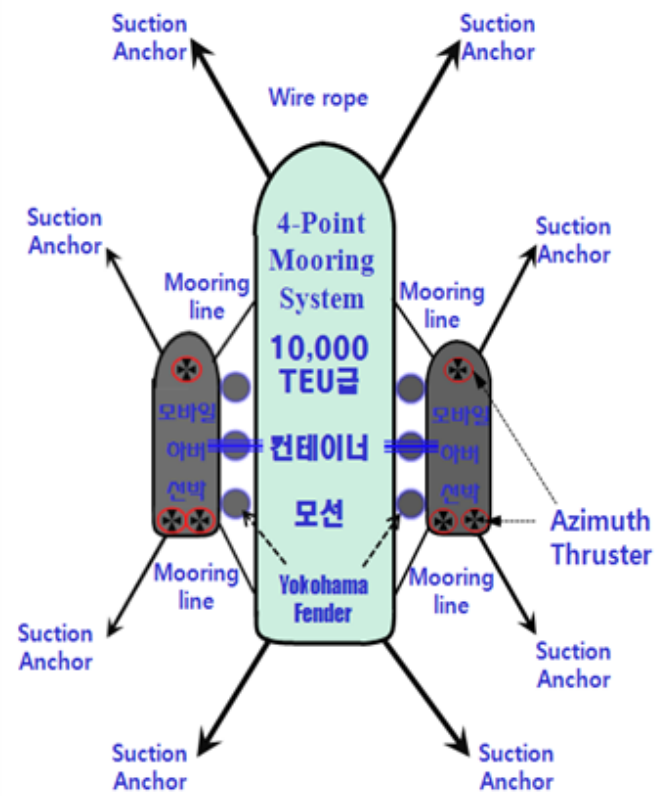

Fig. 1 Conceptual design of mobile harbor

The requirements of a mother ship are the following. However, they are not fully considered because this study is to deal with only dock side test.

- The mother ship will be moored by four-point method in the particular anchorage equipped with four (4) suction pile anchors.

- Mooring ropes will be chains or wire ropes and their specifications are determined depending upon the size of the mother ship.

- The positions of the four pile anchors are determined, considering the prevailing direction of the wind and current in the area.

- To obtain the maximum holding power, the suction pile anchors are established so that their horizontal angles of mooring should be about $30^{\circ}$ of port and starboard respectively with respect to the fore and aft line.

- To reduce the heave motion of the mother ship, the vertical angles of mooring should be close to the right angle if possible. The direction of the right angle is not possible due to the characteristics of the mother ship. Considering other motions except heave one, we determined that the vertical angles of mooring are $30 \sim 45^{\circ}$ with respect to the vertical axis of the mother ship.

The requirements of a $\mathrm{MH}$ ship are almost the same as those of the mother ship.

- To reduce the heave motion, the MH ship is to be anchored by two-point method in the opposite direction of the mother ship and to be united by using mooring lines toward the mother ship.

- The two-point mooring is done by wire ropes and the mooring alongside the mother ship done by mooring lines for the mobile harbor.

- To obtain the maximum holding power as the mother ship does, the horizontal angles of mooring point are to keep about $30^{\circ}$ respectively relative to the fore and aft line of the $\mathrm{MH}$ ship and the vertical angles of mooring about $45^{\circ}$ relative to the vertical axis of the $\mathrm{MH}$ ship.

- Even if the same external forces applied to the mother ship and $\mathrm{MH}$ ship, the phase difference between motions of the two ships could cause damage to the hulls of them. To alleviate the impact on them air fenders are needed on board the $\mathrm{MH}$ ship.

Finally, the requirements of ship-to-ship stabilized mooring systems are discussed. Firstly, assuming that a DP system is carried on board the MH ship, ship-to-ship SMSs are to be developed so as to reduce the heave motion of the MH ship to the maximum. Secondly, the equipment used commonly in general container ships is to be made better or be added partially and applied to the $\mathrm{MH}$ ship as possible as it can. It is because the space and cost available for the equipment should be considered sufficiently.

- The horizontal mooring lines connected with the mother ship \& suction pile anchors can be controlled by DP systems, while the heave motion cannot be. The ship-to-ship SMS should be designed so that the heave motion caused by the size difference of the mother and $\mathrm{MH}$ ships should be reduced so as to do cargo work by cranes.

- The ship-to-ship SMS should be developed by basically using positioning winches, which are to modify a conventional auto-tension winch to fit the $\mathrm{MH}$ ship, and DGPS attitude sensing system, which is to measure the motion of the $\mathrm{MH}$ ship.

- The initial tension of the MH ship mooring lines should be set up to control the heave motion by using constant brake systems, which can play a key role in the 
positioning winches.

The development in the ship-to-ship SMS technology should include the following.

- Even if the force caused by heave motion is greater than the initial load set up, the SMS should keep the appropriate load constantly.

- In case that the $\mathrm{MH}$ ship goes downwards, the mooring line should be hauled in depending on the heave motion.

\section{Dockside tests on the ship-to-ship SMS}

\subsection{Development of the ship-to-ship SMS}

The conceptual design of the mobile harbor and the ship-to-ship SMS suggested in this paper should be tested to verify and validate its reliability and appropriateness. Firstly, a prototype of the SMS for dockside test includes positioning winch system and embedment drag anchor. The prototype was developed as large as it is fit for a barge of LOA $32 \mathrm{~m}$ and breath $12 \mathrm{~m}$ (Lee et al, 2010). Fig.2 shows the main components of the ship-to-ship SMS.

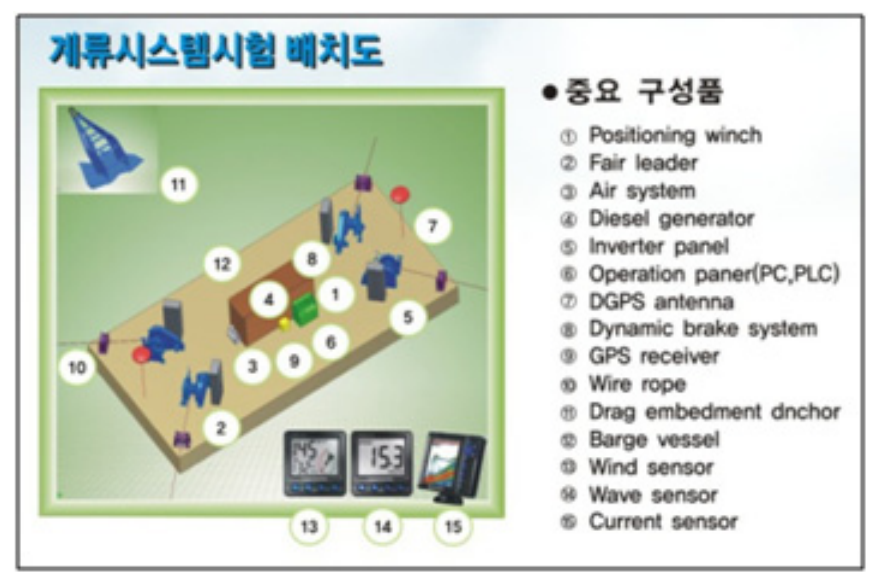

Fig. 2 Arrangement of the ship-to-ship SMS equipment on board a Barge

The type and number of the components for the ship-to-ship SMS used in the test are as follows.

- Positioning winch: 4ea

- Fair leader: 4ea

- DGPS receiver: 4ea

- Wire rope: $40 \Phi$

- Wind \& wave sensor: 1ea

And, details of the positioning winch are as follows.

- Rated pull load: 12 ton
- Type: variable velocity \& variable frequency converted

- Speed control: vector inverter/converter with driving system

- Winding speed: $0 \sim 5 \mathrm{~m} / \mathrm{min}$

- No. of point: 4 positions

- Primary mover: diesel generator

- Power supply: 440V x 60Hz x 3Ph

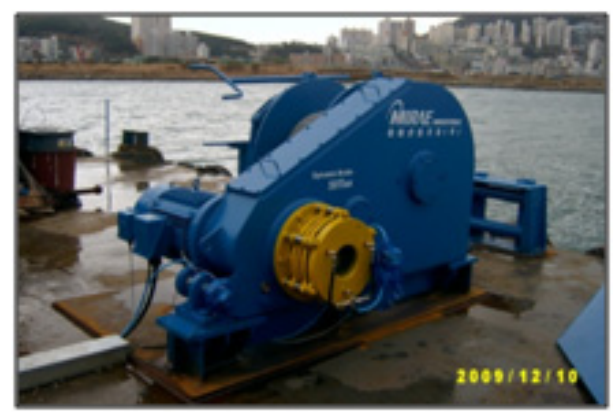

Fig. 3 An example of positioning winch

Particulars of the barge for dockside test are given by the following (Fig. 4).

- LOA: $32 \mathrm{~m}$

- Breadth: 12m

- Full load line: $2.0 \mathrm{~m}$

- Draft of test: $0.4 \mathrm{~m}$

- Block coefficient: 0.96

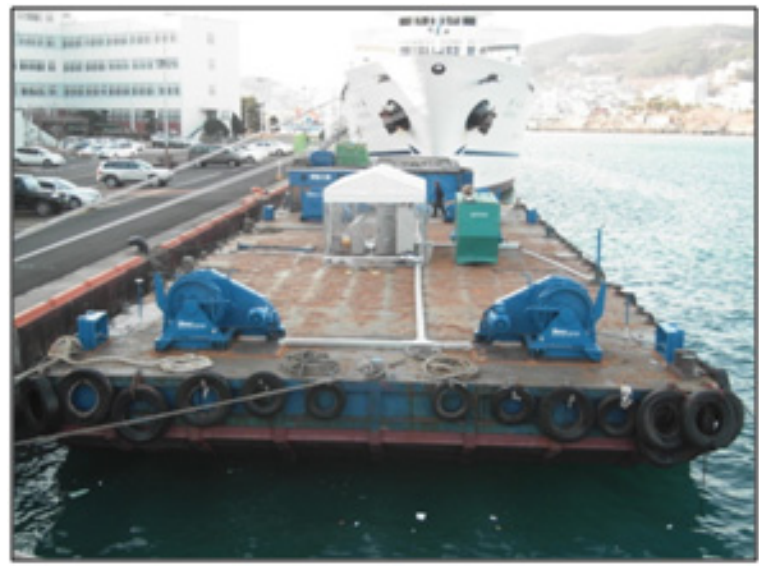

Fig. 4 A barge for dockside tests and equipment aboard it

One of embedment drag anchors is given by the following (Fig. 5).

- Weight: 5 tons

- Expected holding power: 100 tons

Fairleaders were made as roller type to transmit constant tension and reduce frictional wear regardless of the direction of wire ropes(Fig. 6). 


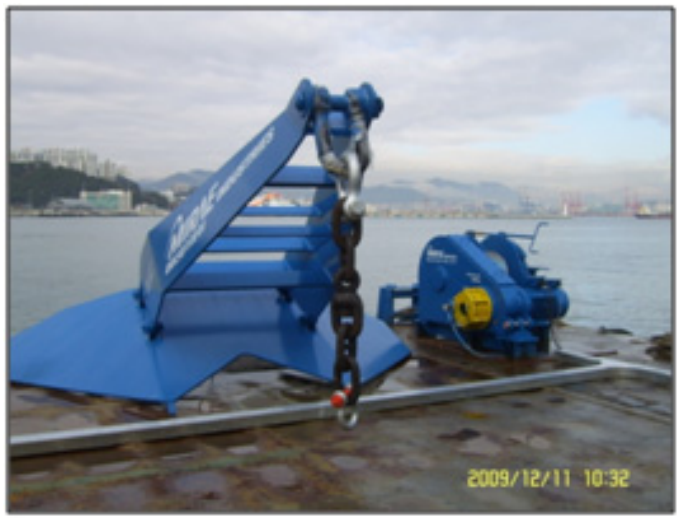

Fig. 5 Embedment drag anchor \& positioning winch

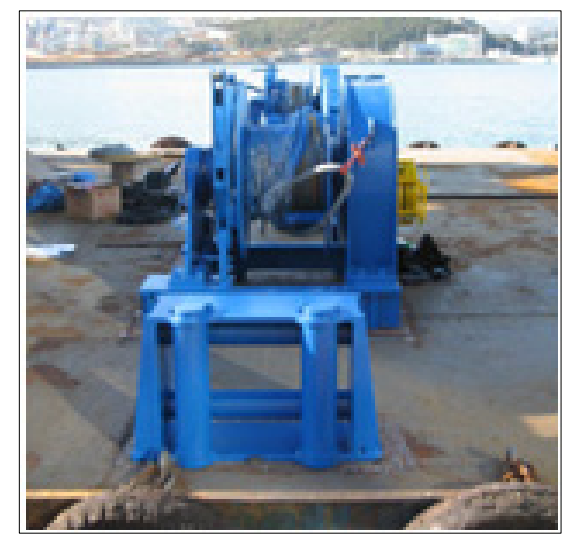

Fig. 6 A fairleader \& positioning winch

\subsection{Results of dockside tests}

The dockside tests were done at the wharf of Korea Maritime University, Busan, Korea from 17 to 23 December, 2009. The tests were carried out based on the almost same condition of sea wave and wind. The motions of the barge with control of the positioning winch and those without control were sensed by four (4) DGPS receivers and recorded respectively. And at that time the wind, current and sea wave were also saved. The tension of each positioning winch was sensed by load-cell and recorded.

The rotary movement of yaw, pitch and roll and the translational movement of surge, sway and heave were determined by analyzing positions obtained from the DGPS receivers. This study is to compare six (6) DOF motions controlled with those uncontrolled and to ascertain whether the SMS developed will be available for the mobile harbor.

Only five (5) results among dockside tests were described. All six DOF motions were analyzed, but due to limited paper space only heave motions were shown here. And it also is because the heave motions of the barge were focused on due to the importance of controlling the vertical motion.

\section{Dockside test No.1}

Time and date of test: 10:30-11:00 Dec. 18, 2009

Height and period of sea wave: average height and period of sea wave during the test are $0.15 \mathrm{~m}$ and $8.76 \mathrm{~s}$ respectively and the maximum height and period $0.28 \mathrm{~m}$ and 4.14 s respectively.

Direction and speed of wind: the wind speed was $2^{\sim} 10$ $\mathrm{m} / \mathrm{s}$ and relative direction with respect to the barge's head $260^{\sim} 350^{\circ}$ during the test.

Heave motion: Fig. 7 shows the heave motions 'controlled' and 'uncontrolled'. In the figure blue line indicates 'controlled motion' and red dash line represents 'uncontrolled motion'. As shown as in Fig. 6 the controlled heave motion is significantly less than the uncontrolled motion.

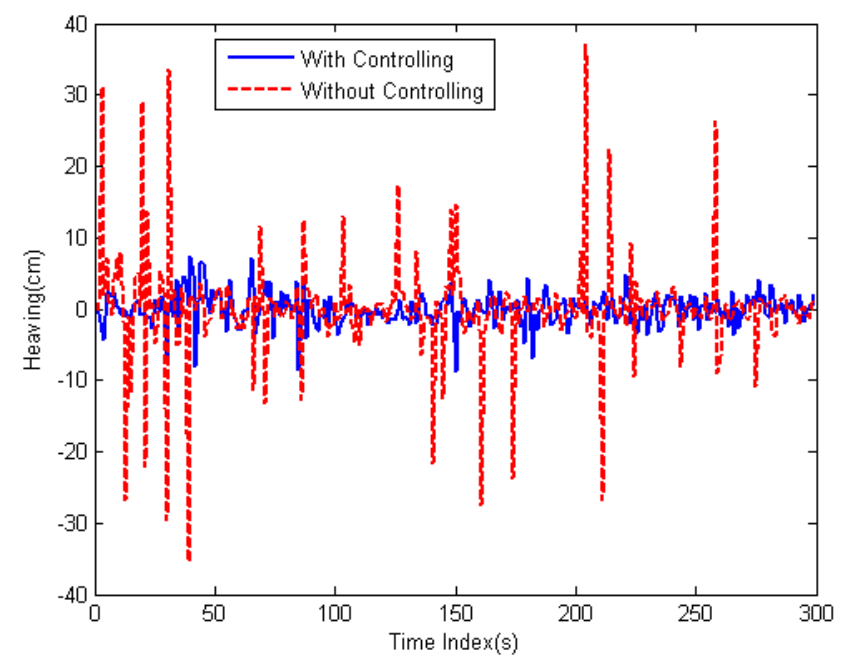

Fig. 7 Comparison of heave motions 'controlled' and 'uncontrolled' on condition of average height $0.15 \mathrm{~m}$ and max height $0.28 \mathrm{~m}$

\section{Dockside test No.2}

Time and date of test: 11:15-11:45 Dec. 18, 2009

Height and period of sea wave: average height and period of sea wave during the test are $0.15 \mathrm{~m}$ and $8.35 \mathrm{~s}$ respectively and the maximum height and period $0.20 \mathrm{~m}$ and 5.3s respectively.

Direction and speed of wind: the wind speed was $2^{\sim} 16$ $\mathrm{m} / \mathrm{s}$ and relative direction with respect to the barge's head $260 \sim 350^{\circ}$ during the test.

Heave motion: Fig. 8 shows the heave motions 'controlled' and 'uncontrolled'. According to Fig. 7 the controlled heave motion is also much less than the uncontrolled motion as it is in the above. 


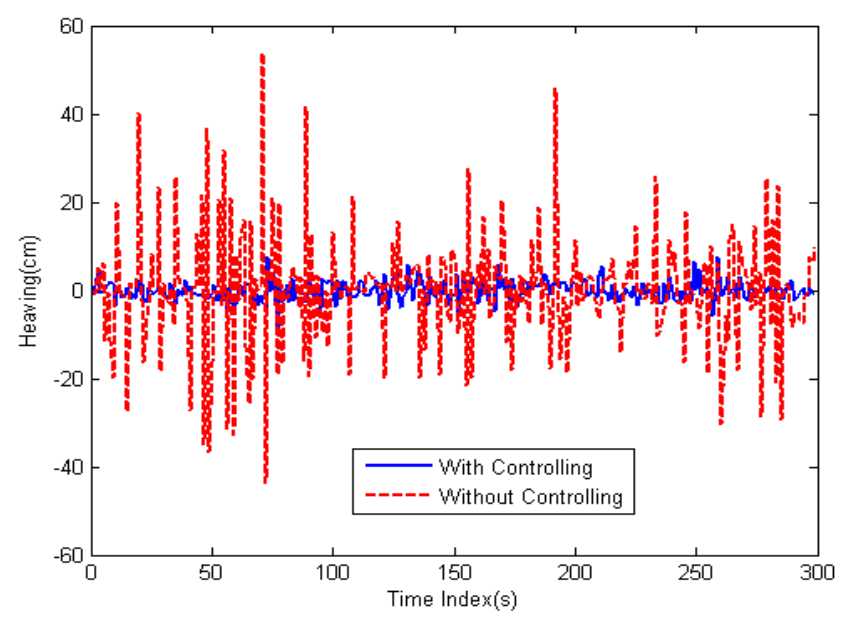

Fig. 8 Comparison of heave motions 'controlled' and 'uncontrolled' on condition of average height $0.15 \mathrm{~m}$ and max height $0.20 \mathrm{~m}$

\section{Dockside test No.3}

$\square$ Time and date of test: 14:15-11:45 Dec. 18, 2009

$\square$ Height and period of sea wave: average height and period of sea wave during the test are $0.16 \mathrm{~m}$ and $7.86 \mathrm{~s}$ respectively and the maximum height and period $0.20 \mathrm{~m}$ and 5.3 s respectively.

Direction and speed of wind: the wind speed was $1^{\sim} 12$ $\mathrm{m} / \mathrm{s}$ and relative direction with respect to the barge's head $260 \sim 360^{\circ}$ during the test.

$\square$ Heave motion: Fig. 9 also shows that the controlled heave motion is significantly less than the uncontrolled motion.

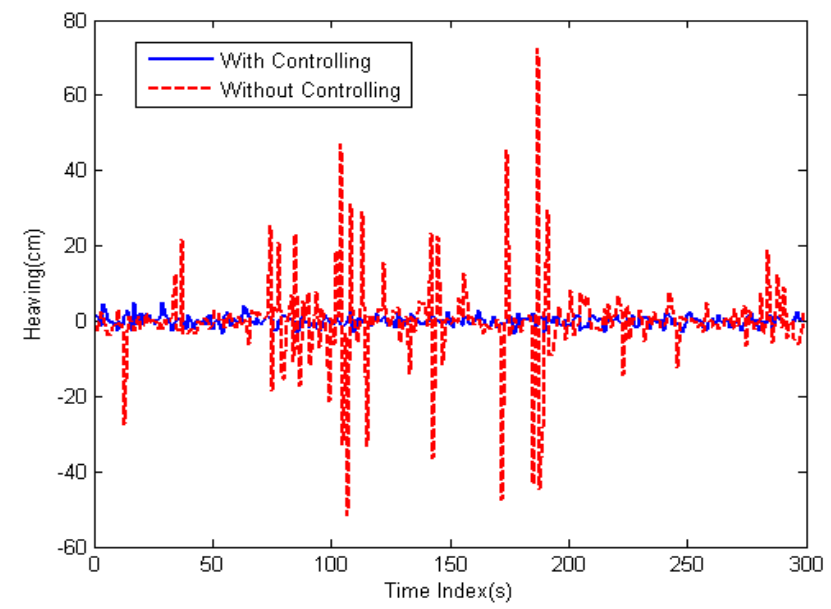

Fig. 9 Comparison of heave motions 'controlled' and 'uncontrolled' on condition of average height $0.16 \mathrm{~m}$ and max height $0.20 \mathrm{~m}$

\section{Dockside test No.4}

$\square$ Time and date of test: 14:15-15:30 Dec. 18, 2009
Height and period of sea wave: average height and period of sea wave during the test are $0.21 \mathrm{~m}$ and $4.94 \mathrm{~s}$ respectively and the maximum height and period $0.35 \mathrm{~m}$ and 3.62 s respectively.

Direction and speed of wind: the wind speed was 4 $123 \mathrm{~m} / \mathrm{s}$ and relative direction with respect to the barge's head $230 \sim 280^{\circ}$ during the test.

$\square$ Heave motion: Fig. 10 also shows that the controlled heave motion is considerably less than the uncontrolled motion.

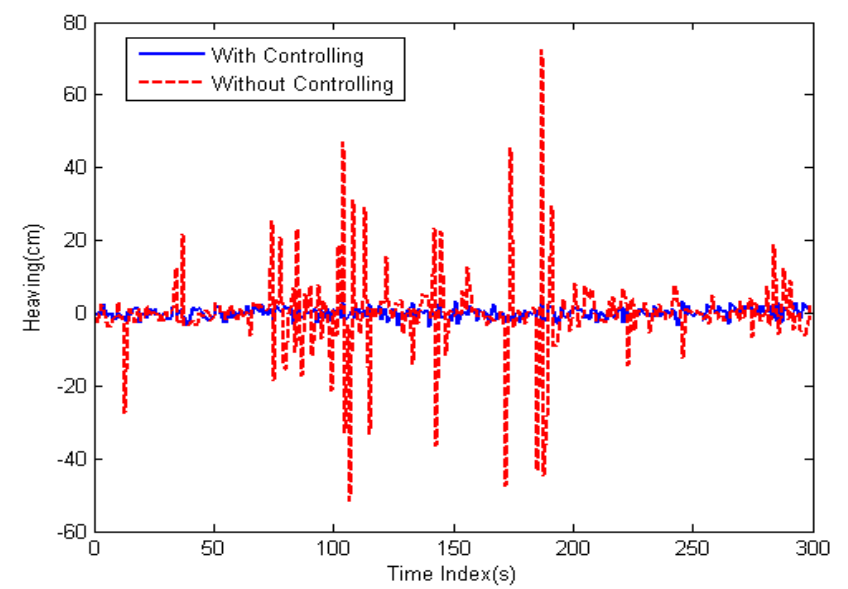

Fig. 10 Comparison of heave motions 'controlled' and 'uncontrolled' on condition of average height $0.21 \mathrm{~m}$ and max height $0.35 \mathrm{~m}$

\section{Dockside test No.5}

$\square$ Time and date of test: 10:50-11:40 Dec. 23, 2009

Height and period of sea wave: average height and period of sea wave during the test are $0.21 \mathrm{~m}$ and $4.94 \mathrm{~s}$ respectively and the maximum height and period $0.35 \mathrm{~m}$ and 3.62 s respectively.

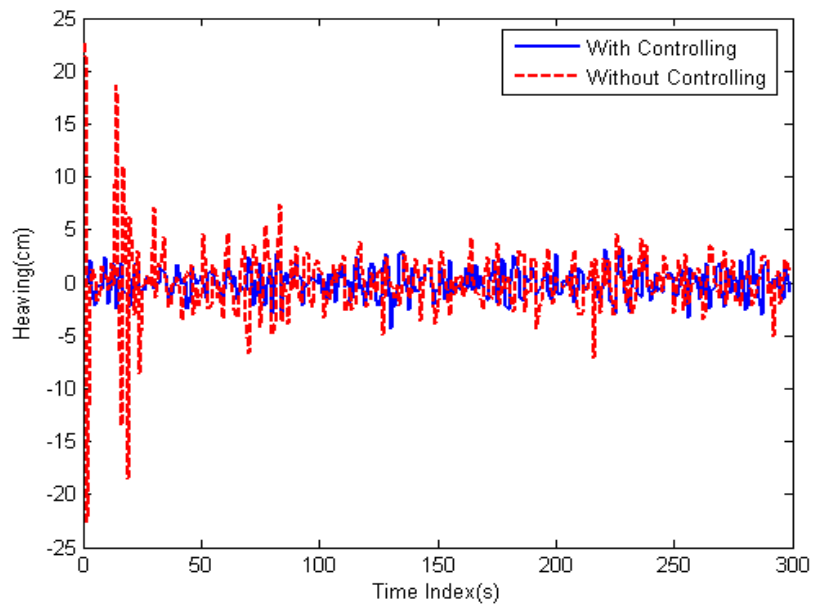

Fig. 11 Comparison of heave motions 'controlled' and 'uncontrolled' on condition of average height $0.21 \mathrm{~m}$ and max height $0.35 \mathrm{~m}$ 
Direction and speed of wind: the wind speed was 4 $10 \mathrm{~m} / \mathrm{s}$ and relative direction with respect to the barge's head $280 \sim 360^{\circ}$ during the test.

$\square$ Heave motion: Fig. 11 also shows that the controlled heave motion is much less than the uncontrolled motion.

\subsection{Discussions}

According to Table 1 the above-mentioned dockside tests have shown that the heave motions can be decreased by more than $45 \%$. It has been found that the ship-to-ship SMS can work well to reduce the heave motion of the MH ship.

Table 1 Reduced ratio of heave motions

\begin{tabular}{|c|c|c|c|c|}
\hline \multirow{2}{*}{ Test } & \multicolumn{2}{|c|}{ Wave(m) } & \multirow{2}{*}{$\begin{array}{c}\text { Wind } \\
\text { speed } \\
(\mathrm{m} / \mathrm{s})\end{array}$} & $\begin{array}{c}\text { Reduced heave } \\
\text { motion(\%) }\end{array}$ \\
\cline { 2 - 3 } & Ave & Max & $2 \sim 10$ & 51.72 \\
\hline 1 & 0.15 & 0.28 & $2 \sim 16$ & 79.51 \\
\hline 2 & 0.15 & 0.20 & $2 \sim 12$ & 79.94 \\
\hline 3 & 0.16 & 0.22 & $1 \sim 12$ & 77.83 \\
\hline 4 & 0.16 & 0.22 & $4 \sim 12$ & 45.16 \\
\hline 5 & 0.21 & 0.35 & $4 \sim 10$ & \\
\hline
\end{tabular}

\section{Conclusions}

This study suggested one of the conceptual designs of mobile harbor and for the ship-to-ship SMS carried out dockside tests to validate the conceptual mobile harbor. As a result, the following are concluded.

- To keep ship-to-ship stabilized mooring, we suggested that the mother ship be moored with four-point suction pile anchors and wire ropes and also the $\mathrm{MH}$ ship be moored with two-point suction pile anchors and wire ropes outwards and with wire ropes and Yokohama fenders towards the mother ship.

- The dockside tests were carried out to check the motion of a barge of $400 \mathrm{CBM}$ alongside the wharf, Korea Maritime University. The barge was moored with four (4) positioning winch systems, 4 DGPS sensors, wave meter, and anemometer.

- The translational movement of the barge such as heave, surge and sway motion is generally less at the state controlled by positioning winches than at the state without control.

- The heave motion of the barge decreased by more than $45 \%$ during dockside tests.

This study carried out dockside tests under less than sea state 3 due to experimental cost and short period. In the future study sea tests should be done under the condition of more than sea state 3 and the mooring alongside a mother ship near the coast of Korea.

\section{Acknowledgements}

This research was part of the results of the project called "the Development of Ship-to-Ship Stabilized Mooring System and Equipment concerned" supported by a grant from "the Development Program of Original Technologies for Mobile Harbor" funded by the Ministry of Education, Science and Technology. This paper was presented in MARTECH 2010- 9th Bienniel International Conference and Exhibition 27th Apr - 2nd May, 2010, in Singapore.

\section{References}

[1] Jang, T.S.(2009), "Simultaneous nonparametric identification of nonlinear roll damping and restoring moment of a mobile harbor", 2009 Mobile Harbor R\&D Workshop, KAIST.

[2] Kim, K.S.(2009), "The Development of Zero Moment Crane Stabilized Control System”, 2009 Mobile Harbor R\&D Workshop, KAIST

[3] Kim, S.H.(2009), “The Conceptual Design of Mobile Harbor Floaters”, 2009 Mobile Harbor R\&D Workshop, KAIST.

[4] Lee, K.G. et al(2010),"Development of the Prototype Positioning Winch and Drag Anchor for Mobile Harbor", The Joint Conference Proceedings-KINPR, pp.216-218.

[5] Lee J.M.(2009), “The Development of High-speed Cargo Handling System for Mobile Harbor and Stabilization of Floating Objects”, 2009 Mobile Harbor R\&D Workshop, KAIST

[6] Myung H. (2009), “A Hybrid Path Planning for Multiple Mobile Harbor Navigation", 2009 Mobile Harbor R\&D Workshop, KAIST.

[7] Park U.S. (2009), "The Development of Wave Control System for Mobile Harbor", 2009 Mobile Harbor R\&D Workshop, KAIST.

[8] Park Y.S. (2009), "Dynamic Analysis of Floating Mobile Harbor and Development of Control Strategies", 2009 Mobile Harbor R\&D Workshop, KAIST.

[9] Shin Y.S. (2009), "Simulational and Experimental Study on the Seakeeping Performance of the MH A-1 type Mobile Harbor", 2009 Mobile Harbor R\&D Workshop, KAIST.

Received 13 May 2010

Revised 23 June 2010

Accepted 23 June 2010 